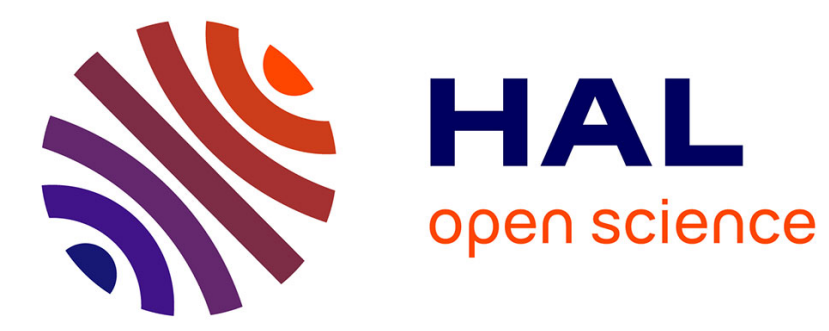

\title{
Price setting and price adjustment in some European Union Countries: introduction to the special issue
}

Daniel Levy, Frank Smets

\section{To cite this version:}

Daniel Levy, Frank Smets. Price setting and price adjustment in some European Union Countries: introduction to the special issue. Managerial and Decision Economics, 2010, 31 (2-3), pp.63-66. 10.1002/mde.1502 . hal-02387735

\section{HAL Id: hal-02387735 \\ https://hal.science/hal-02387735}

Submitted on 30 Nov 2019

HAL is a multi-disciplinary open access archive for the deposit and dissemination of scientific research documents, whether they are published or not. The documents may come from teaching and research institutions in France or abroad, or from public or private research centers.
L'archive ouverte pluridisciplinaire HAL, est destinée au dépôt et à la diffusion de documents scientifiques de niveau recherche, publiés ou non, émanant des établissements d'enseignement et de recherche français ou étrangers, des laboratoires publics ou privés. 
Forthcoming

Managerial and Decision Economics, 2010

Special Issue - Price Setting and Price Adjustment in Some European Union Countries

\title{
Price Setting and Price Adjustment in Some European Union Countries
}

\section{Introduction to the Special Issue}

\author{
Daniel Levy ${ }^{\mathrm{a}, \mathrm{b}, \mathrm{e}, *}$ and Frank Smets ${ }^{\mathrm{c}, \mathrm{d}, \mathrm{f}}$ \\ Guest Editors of the Special Issue \\ ${ }^{a}$ Department of Economics, Bar-Ilan University, Ramat-Gan 52900, ISRAEL \\ ${ }^{\mathrm{b}}$ Department of Economics, Emory University, Atlanta, GA 30322, USA \\ ${ }^{\mathrm{c}}$ Research Department, European Central Bank, Frankfurt am Main, GERMANY \\ ${ }^{\mathrm{d}}$ Faculty of Business and Economics, University of Groningen, Groningen, NETHERLANDS \\ ${ }^{\mathrm{e}}$ Rimini Centre for Economic Analysis, Rimini, ITALY \\ ${ }^{\mathrm{f}}$ CEPR, London, THE UNITED KINGDOM
}

Abstract: This introductory essay briefly summarizes the eleven empirical studies of price setting and price adjustment that are included in this special issue. The studies, which use data from several European countries, were conducted as part of the European Central Bank’s Inflation Persistence Network.

* Correspondence to:

Department of Economics, Bar-Ilan University, Ramat-Gan 52900, ISRAEL;

Tel: +972-3-531-8331; Fax: +972-3-535-3180; Email: Levyda@ mail.biu.ac.il.

Last Revision: February 11, 2010

JEL Codes: D21, D40, E12, E31, E50, E52, E58, L11, L16, M20, M30

Key Words: Price Rigidity, Price Flexibility, Cost of Price Adjustment, Menu Cost, Managerial and Customer Cost of Price Adjustment, Pricing, Price System, Price Setting, New Keynesian Economics, Store-Level Data, Micro-Level Data, Product-Level Data 


\section{INTRODUCTION}

An age old question in economics is, to what extent do prices adjust to changes in market conditions? In other words, how rigid or flexible prices are. Up until the beginning of the 1990s, there were hardly any studies of price rigidity that use micro level (i.e., store-level and/or product-level) data on actual transaction prices. The last 1520 years have witnessed a remarkable revival in the popularity of New Keynesian models which incorporate various forms of rigidities as the main source of friction needed to generate monetary non-neutrality. See, for example, Mankiw and Romer (1991a, 1991b) and Sheshinski and Weiss (1993), and the references cited therein.

The renewed attention to the theoretical New Keynesian research program has revived the economists' interest in empirical aspects of price rigidity. Consequently, the New Keynesian macroeconomics and to a lesser extent the industrial organization literatures, began offering empirical studies of price rigidity using various types of microlevel data from the US as well as from the European Union countries. ${ }^{1}$

Two previous special issues of the Managerial and Decision Economics were devoted to this research topic. One previous special issue (Levy, 2007a) was devoted to some recent theoretical developments in this line of research. A sequel (Levy, 2007b), reported the findings of some of the most recent empirical studies of price rigidity. The goal of this special issue is to report the results of some recent additional empirical studies that use micro level retail and wholesale transaction price data as well as some new survey data from several European Union countries.

These studies were undertaken by the European Central Bank's (ECB's) Inflation Persistence Network (IPN). The IPN, which was a research team consisting of economists from the ECB and the national central banks of the Eurosystem, was set up by these institutions in order to conduct a coordinated research project on the patterns, determinants and implications of inflation persistence in the euro area and in its member countries. The main issues the IPN studies addressed were (a) existence and characterization of nominal rigidities in the Euro area, (b) determinants of nominal rigidities, and (c) empirical testing of alternative price setting models.

\footnotetext{
${ }^{1}$ See Willis (2003) and Wolman (2007) for recent surveys of some of these studies.
} 
These studies addressed numerous particular questions of interest. For example: Are prices rigid in the Euro area? Are these rigidities symmetric? What are the sources of the price rigidities? Are these sources similar across countries? Are there systematic patterns in the differences found across countries, products and/or sectors in the degree of price stickiness? Which factors beyond nominal rigidities are needed to explain this inflation persistence? Etc.

For this purpose, the ECB and the member countries' central banks have provided the IPN teams with incredibly detailed data sets, containing numerous macroeconomic and sector-level variables, as well as data and information on price-setting and price adjustment behavior at the individual firm level. The individual price records used in the construction of both consumer price index (CPI) and producer price index (PPI) have been made available in a large number of EU countries. In addition, the IPN has conducted surveys on price setting behavior in nine countries of the euro area.

\section{IN THIS ISSUE}

This special issue of the Managerial and Decision Economics contains 11 contributions from various IPN teams. ${ }^{2}$ These papers address empirically various aspects of price rigidity and flexibility from different angles and points of view, using different types of data from 10 different countries. These include Germany, Italy, Spain, Portugal, the Netherlands, Austria, Hungary, Luxembourg (two studies), Slovakia, and Romania.

In "Price Adjustment in German Manufacturing: Evidence from Two Merged Surveys," Harald Stahl presents evidence on formation of producer prices in German manufacturing, using two survey data sets on 1,200 German firms. He finds that twenty percent of the firms' price setting behavior resembles time-dependent price setting rules. It turns out, however, that neither Taylor nor Calvo-type price setting rules seem to describe well the sampled firms' price setting behavior. Stahl concludes that fixed contracts and coordination failures are the main reason for delay in price adjustment decisions although the hazard rates for price changes do not support this.

\footnotetext{
2 Other published studies from the IPN network include Alvarez, L.J., et al. (2006), Angeloni, I., et al. (2006), Dhyne, E., et al. (2006), and Fabiani, S., et al. (2007). For a complete list of the studies that were conducted as part of the IPN network, see http://www.ecb.int/home/html/researcher_ipn_papers.en.html.
} 
In "Price Adjustment in Italy: Evidence from Micro Producer and Consumer Prices," Silvia Fabiani, Angela Gattulli, Giovanni Veronese and Roberto Sabbatini report that Italian producer prices remain unchanged for about 6 months, while consumer prices exhibit a longer duration of 10 months. They report that prices are more flexible at the production stage. They find that a higher labour share in total costs is related to lower frequency of price adjustment. The authors hypothesise that the structure and functioning of the retail sector in Italy together with other specific factors (e.g., menu costs or psychological pricing policies), may slow price adjustment at the consumption stage.

In "Price Setting Behaviour in Spain: Evidence From Micro PPI Data," Luis Álvarez, Pablo Burriel and Ignacio Hernando study the price setting behaviour at Spain's manufacturing industry using a rich micro-level PPI dataset. They find that some important variables, including the cost structure, degree of market competition, demand conditions and inflationary pressures have substantial impact on the frequency of price adjustment and thus contribute to the heterogeneity of price stickiness across industries. They compare the consumer and the producer price setting practices and find evidence that producer prices are more flexible than consumer prices.

In "Price Stickiness in Portugal: Evidence from Survey Data," Fernando Martins presents evidence indicating a considerable degree of price stickiness in Portugal. For example, he finds that most firms do not change prices more than once a year. He also finds that the time lag in price reaction to shocks is significant. Implicit contracts between firms and their customers which "promise" stable prices seem to prevent the firms from changing their prices more frequently.

In "Price Setting Behaviour in the Netherlands: Results of a Survey," Marco Hoeberichts and Ad Stokman use a survey of Dutch firms' price setting practices. Their primary finding is that Dutch firms' price setting behaviour depends critically on both a firm's size and the competitive environment. For example, small firms' prices are more rigid. The weaker the competition is, the stickier the firm's price. Their survey suggests that contracts (explicit and implicit) may be the key source of price rigidity.

In "How Are Prices Adjusted in Response to Shocks? Survey Evidence from Austrian Firms," Claudia Kwapil, Johann Scharler, and Josef Baumgartner, study price response to shocks using Austrian firm survey data. They find that firms are more likely 
to adjust prices after a cost shock than after a demand shock. Their analysis suggests customer loyalty plays a key role in explaining price rigidity in response to demand shocks. Furthermore, a lack of competition seems to play a substantial role in explaining price stickiness. Finally, they find asymmetric responses after cost and demand shocks. It seems that after cost shocks, downward price rigidity is more frequent than upward price rigidity, while the opposite is true after shifts in demand.

In "Price Setting in Hungary - A Store-Level Analysis," Péter Gábriel and Ádám Reiff study the Hungarian micro CPI data to characterize store-level pricing practices in Hungary. They report the frequency and average size of price changes, the duration distribution of price spells and the mean durations for different product categories. They decompose the observed variations in the inflation rate into variations in frequencies and variation in sizes. Finally, they estimate the inflation effects of three general VAT-rate changes during the sample period.

Patrick Lünnemann and Thomas Y. Mathä contribute two papers to the special issue. In "Consumer Price Behavior: Evidence from Luxembourg Micro Data," they report that the median duration of consumer prices is about 8 months. With the exception of services, prices are not rigid downwards. They find that price changes are determined both by state- and time-dependent factors. Accumulated price and wage inflation, and the cash changeover increase the price change probability, while pricing at psychological pricing points and price regulation have the opposite effect. Automatic wage indexation increases the probability of price increases, especially in consumer product categories where prices are closely linked to wage costs.

In “Regulated and Services Prices’ Rigidities and Inflation Persistence: Some Observations," Lünnemann and Mathä study price level rigidity and inflation persistence using about 1500 price indices for the EU15 member states. Services and harmonized indexes of consumer prices (HICP) subject to price regulation exhibit a larger degree of nominal price rigidity, with less frequent but larger changes as well as stronger asymmetries between increases and decreases. For most of the EU15 countries as well as for the EU15 and the euro area aggregates, excluding services from the full HICP reduces the measured degree of inflation persistence. 
In "Price Setting and Market Structure: An Empirical Analysis of Micro Data in Slovakia," Fabrizio Coricelli and Roman Horváth find that the market structure is a key determinant of price setting behaviour. Market structure has two opposing effects on inflation persistence. On the one hand, increased competition may reduce persistence by increasing the frequency of price changes. On the other hand, higher competition may increase persistence through inertial behaviour induced by strategic complementarities among price setters. They find that the latter effect dominates. Indeed, the dispersion of prices is higher while persistence is lower in the non-tradable sectors, suggesting that higher competition is not conducive to lower persistence. Furthermore, they report that the frequency of price changes depends negatively on the price dispersion and positively on the product-specific inflation.

In "Survey Evidence on Price Setting Patterns of Romanian Firms," Mihai Copaciu, Florian Neagu, and Horia Braun-Erdei present the results of the first micro survey on price setting patterns among the New Member States of the European Union (NMS). Diverging from other IPN studies' findings, small firms perceive higher competitive pressures and set prices using a state dependent rule. Lower perceived competition seems to be more relevant for the medium and large firms which use mark-up pricing. Prices are reviewed and changed more often than for EMU firms and are found to be more flexible than wages. Similar to other IPN studies' evidence, contracts are the main sources of price stickiness. The survey also suggests full price transmission of large unanticipated financial shocks.

\section{ACKNOWLEDGEMENTS}

Much of the editorial work on this special issue was completed at the Monetary Policy and Research Division of the Research Department, at the European Central Bank (Frankfurt), where Daniel Levy was a Visiting Scholar. He is grateful to the Bank's Research Department Director at the time, Vitor Gaspar, to the Department's research economists, and to the Bank's management and the administrative staff for their kind hospitality. Daniel Levy gratefully acknowledges also the financial support from the Adar Foundation of the Economics Department at Bar-Ilan University. We thank our colleagues Bob Barsky, Mark Bergen, Allan Chen, Sourav Ray, Paul Rubin, Avichai 
Snir, Andy Young, and Mark Zbaracki for comments and advice throughout the editorial process. $M D E$ 's managing editors during the last few years, Soyong Chong, Mike Hammock, Shireen Meer, and Mary Schroeder provided efficient editorial assistance in the editing and processing of the special issue. We are grateful to the $M D E$ 's editor-inchief, Paul Rubin for the continuous support and encouragement. Finally, we thank Wiley's editorial personnel, Russel Graham and Ivry Tan, for their assistance in preparing and processing this special issue for publication. 


\section{REFERENCES}

Alvarez, L.J., et al. 2006. Sticky prices in the Euro area: a summary of new microevidence. Journal of European Economic Association 4: 575-584.

Angeloni, I., et al. 2006. New evidence on inflation persistence and price stickiness in the euro area: implications for macro modeling. Journal of the European Economic Association 4: 562-574.

Dhyne, E., et al. 2006. Price changes in the Euro Area and the United States: Some facts from individual consumer price data. Journal of Economic Perspectives 20: 171-192.

Fabiani, S., et al. 2007. Pricing Decisions in the Euro Area: How Firms Set Prices and Why. Oxford University Press: New York, NY.

Levy, D. 2007a. Price rigidity and flexibility: Recent theoretical developments, introduction to the special issue. Managerial and Decision Economics 28: 523-530.

Levy, D. 2007b. Price rigidity and flexibility: New empirical evidence, introduction to the special issue. Managerial and Decision Economics 28: 639-647.

Mankiw NG, Romer D (ed.). 1991a. New Keynesian Economics, Volume 1, Imperfect Competition and Sticky Prices. The MIT Press: Cambridge, MA.

Mankiw NG, Romer D (ed.). 1991b. New Keynesian Economics, Volume 2, Coordination Failures and Real Rigidities. The MIT Press: Cambridge, MA.

Sheshinski E, Weiss Y (ed.). 1993. Optimal Pricing, Inflation, and the Cost of Price Adjustment. The MIT Press: Cambridge, MA.

Willis, J.L. 2003. Implications of structural changes in the U.S. economy for pricing behavior and inflation dynamics, Federal Reserve Bank of Kansas City Economic Review, First quarter: 5-27.

Wolman A. 2007. The frequency and costs of individual price adjustment. Managerial and Decision Economics 28: 531-552. 